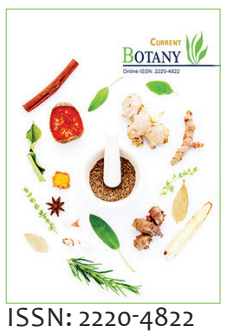

ISSN: 2220-4822
Received: October 02, 2019

Revised: April 14, 2020

Accepted: April 16, 2020

Published: April 18, 2020

*Corresponding Author:

Ashok Kumar Dhakad

Email: ashokdhakad@pau.edu

\section{Molecular taxonomy of Indopiptadenia oudbensis (Brandis) Brenan (Leguminosae - Mimosoideae) - A threatened Indian endemic monotypic genus}

\author{
Ashok Kumar Dhakad ${ }^{1,4 *}$, Vijay Vardhan Pandey², Rahul Kumar³, \\ Ajay Thakur ${ }^{3}$, Anup Chandra' and Praveen Kumar Verma' \\ 'Systematic Botany Discipline, Forest Research Institute, Dehradun, Uttarakhand, Uttarakhand-248006, India, \\ ${ }^{2}$ Molecular Lab, Forest Pathology Discipline, Forest Research Institute, Dehradun, Uttarakhand-248006, India, \\ ${ }^{3}$ Genetics and Tree Propagation Division, Forest Research Institute, Dehradun, Uttarakhand-248006, India, \\ ${ }^{4}$ Department of Forestry \& Natural Resources, Punjab Agricultural University, Ludhiana, Punjab-141004, India
}

\begin{abstract}
Indopiptadenia oudhensis (Brandis) Brenan is a threatened and an endemic legume forest tree genus of tropical moist deciduous forest of lower foothills of Himalava. As population status of the species is declining at alarming rate, molecular characterization and germplasm conservation is urgently needed. This is the first attempt to draw its phylogeny at molecular level and evolutionary closeness with other legumes. Among three barcode genes i.e rbcL, matK and ITS, only $r b c L a F-r b c L a R$ gave satisfactory amplification and proved that $r b c L$ is still working well than other barcode genes and justifies the evolutionary affinities with other legume species. Based on nucleotide homology, the species is closely related to Prosopis cineraria and demonstrated nucleotide variation at only one site (552; A>G). Based on rbcL gene sequences and phylogeny, its evolutionary linkages found similar to the species placed in subfamilies Mimosaoideae and Caesalpiniodeae. However, researchers working on legume phylogeny clearly mentioned that Indopiptadenia is a part of clade mimosoid of Caesalpinioideae based on morphology. Hence, Indopiptadenia oudhensis may be the connecting species between subfamilies Mimosaoideae and Caesalpiniodeae.
\end{abstract}

KEYWORDS: Indopiptadenia oudhensis, threatened, Indian endemic, barcode gene, molecular characterization, phylogenetics

\section{INTRODUCTION}

Indopiptadenia oudhensis (Brandis) Brenan (Syn. Piptadenia oudhensis Brandis), a monotypic genus belongs to family Leguminosae (subfamily-Mimosoideae). The genus is endemic and distributed in the central parts of lower foothills of the Himalaya in the border zone between India and Nepal especially the Terai region of the Bhabar zone [1] which lies in tropical moist deciduous forest [2]. It is commonly known as Gainti and Hathipaula. Its scattered populations were reported between 150-900 $\mathrm{m}$ altitudes [3]. In Uttarakhand (India), species is endemic to Champaran district and categorized as threatened (http://sbb.uk.gov.in/files/books/Threatened_Species_BookCTP.pdf). It is at the verge of extinction because of excessive lopping by local forest communities which affects its seed production and regeneration potential. Another limitation is its confinement to small patch of North India and Western Nepal. Therefore, conservation strategies should be emphasized to avoid the extinction of this monotypic genus.

As per the Bentham and Hooker [4] classification, Momosoideae considered as subfamily and separate family in Indian herbaria [5], however, traditionally recognized subfamily Mimosoideae is a distinct clade nested within the recircumscribed Caesalpinioideae and is referred to informally as the mimosoid clade pending a forthcoming formal tribal and/ or clade based classification of the new Caesalpinioideae [6]. Within Mimosoideae, genera of tribe Ingeae and Acacieae

Copyright: (C) The authors. This article is open access and licensed under the terms of the Creative Commons Attribution License (http://creativecommons.org/licenses/by/4.0/) which permits unrestricted, use, distribution and reproduction in any medium, or format for any purpose, even commercially provided the work is properly cited. Attribution — You must give appropriate credit, provide a link to the license, and indicate if changes were made. 
that have numerous anthers, while, it has ten anthers and other genera of tribe Mimoseae have less than 10 anthers. The species shows more affinity towards the Newtonia genus than the Piptadenia genus. However, it differs from the former in having different morphological characteristics [1]. Indopiptadenia is sometimes confused with the genus Adenanthera Linnaeus (1753:384) which chiefly differs in having a pod with valves that often twist after opening and seeds which are thick, with a hard red or bicoloured testa. In general appearance it resembles with Hardwickia binata Roxburgh (1819:209) and Bauhinia variegata Linnaeus (1753: 375) (Leguminosae-Caesalpinioideae). Thus, the identification based on sole morphological characters can lead to ambiguity and molecular characterization is required.

No systematic study at molecular level has been carried out in Indopiptadenia since its discovery in 1874. Indeed, the sister group relationship of Indopiptadenia remains to be ascertained because the genus shows a unique combination of mimosoid morphological features. This poorly understood monospecific genus is the only genus of mimosoid legumes that has not been sequenced and including in any phylogenetic analysis so far. Thus this study is potentially useful and interesting for those involved with legume systematics.

\section{MATERIALS AND METHODS}

\section{Taxon Sampling}

The present study was conducted in the Systematic Botany Discipline of Botany Division \& Genetics and Tree Propagation Division, Forest Research Institute (FRI), Dehradun, Uttarakhand, India. Juvenile leaf material of mature tree (20-yr-old tree) of I. oudhensis for genetic analysis and twig with flower and fruit (Fig. la) for preparation of voucher specimen were collected from Tanakpur, Champawat, Uttarakhand, India $\left(29^{\circ} 09^{\prime} 56.29^{\prime \prime} \mathrm{N} ; 80^{\circ} 05^{\prime} 24.50^{\prime \prime} \mathrm{E} ; 1116 \mathrm{asml}\right)$. The requisite numbers of samples of I. oudhensis was collected randomly from study area and tagged with proper identity and bagged separately. Voucher specimen was prepared and submitted to the DD Herbarium, FRI Dehradun for authentic identification and cross verification (Fig. lb). The fresh leaf material for molecular studies was stored at $-80^{\circ} \mathrm{C}$.

\section{DNA Amplification and Sequencing}

The protocol established by Kumar et al. [7] with some modifications and DNeasy Mini Plant Kit-QIAGEN were tested for yield, quality and suitability for sequencing analysis. Genomic DNA quality was evaluated on $0.8 \%$ agarose with IX TBE buffer, stained with ethidium bromide $(0.5 \mu \mathrm{g} / \mathrm{ml})$ and quantity with Biophotometer (Eppendorf-6131, Germany) using A260/A280 nm wavelength and the concentration of DNA was determined in term of $\mathrm{ng} / \mu \mathrm{l}$ [8]. Three barcode genes listed in Table 1 viz., rbcL, matK and ITS were tried. PCR reaction

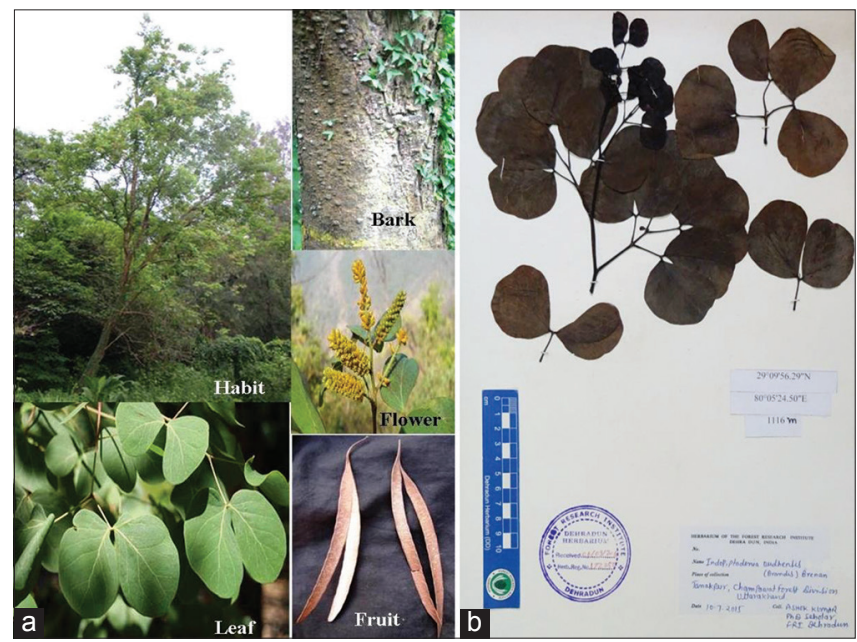

Figure 1: (a) Representative species; (b) Voucher specimen

Table 1: Sequences of oligonucleotide primers used for PCR amplification and sequencing of the plastid gene in legumes. Sequences given are all $5^{\prime}$ to $3^{\prime}$; forward and reverse refer to direction with respect to coding sequence [5]

\begin{tabular}{|c|c|c|}
\hline Primers & Sequences $5^{\prime}-3^{\prime}$ & PCR steps \\
\hline$r b c L a F$ & $\begin{array}{l}\text { TGTCACCACAAACAGAGACTAAAGC } \\
\text { GTAAAATCAAGTCCACCRCG }\end{array}$ & $\begin{array}{l}\text { Initial denaturation temperature : } 98^{\circ} \mathrm{C} \text { for } 45 \mathrm{sec} \\
\text { Denatutration temperature }: 98^{\circ} \mathrm{C} \text { for } 10 \mathrm{sec}\end{array}$ \\
\hline$r b c L a R$ & & $\begin{array}{l}\text { Primer annealing temperature : } 55^{\circ} \mathrm{C} \text { for } 30 \mathrm{sec} \\
\text { Strand extension temperature : } 72^{\circ} \mathrm{C} \text { for } 40 \mathrm{sec} \\
\text { Final extension temperature : } 72^{\circ} \mathrm{C} \text { for } 10 \mathrm{~min}\end{array}$ \\
\hline$r b c L 1 F$ & $\begin{array}{l}\text { ATGTCACCACAAACAGAAAC } \\
\text { TCCTTTTAGTAAAAGATTGGGCCGAG }\end{array}$ & $\begin{array}{l}\text { Initial denaturation temperature : } 95^{\circ} \mathrm{C} \text { for } 1 \mathrm{~min} \\
\text { Denatutration temperature }: 95^{\circ} \mathrm{C} \text { for } 30 \mathrm{sec}\end{array}$ \\
\hline$r b c L 724 \mathrm{R}$ & & $\begin{array}{l}\text { Primer annealing temperature : } 48^{\circ} \mathrm{C} \text { for } 30 \mathrm{sec} \\
\text { Strand extension temperature : } 68^{\circ} \mathrm{C} \text { for } 60 \mathrm{sec} \\
\text { Final extension temperature : } 68^{\circ} \mathrm{C} \text { for } 5 \mathrm{~min}\end{array}$ \\
\hline matK390F & $\begin{array}{l}\text { CGATCTATTCATTCAATATTTC } \\
\text { TCTAGCACACGAAAGTCGAAGT }\end{array}$ & $\begin{array}{l}\text { Initial denaturation temperature : } 95^{\circ} \mathrm{C} \text { for } 10 \mathrm{~min} \\
\text { Denatutration temperature }: 95^{\circ} \mathrm{C} \text { for } 20 \mathrm{sec}\end{array}$ \\
\hline matK1326R & & $\begin{array}{l}\text { Primer annealing temperature : } 50^{\circ} \mathrm{C} \text { for } 15 \mathrm{sec} \\
\text { Strand extension temperature }: 72^{\circ} \mathrm{C} \text { for } 90 \mathrm{sec} \\
\text { Final extension temperature : } 72^{\circ} \mathrm{C} \text { for } 90 \mathrm{sec}\end{array}$ \\
\hline ITS4 & $\begin{array}{l}\text { TCCTCCGCTTATTGATATGC } \\
\text { GGAAGTAAAAGTCGTAACAAGG }\end{array}$ & $\begin{array}{l}\text { Initial denaturation temperature : } 94^{\circ} \mathrm{C} \text { for } 4 \mathrm{~min} \\
\text { Denatutration temperature : } 94^{\circ} \mathrm{C} \text { for } 80 \mathrm{sec}\end{array}$ \\
\hline ITS5 & & $\begin{array}{l}\text { Primer annealing temperature : } 60^{\circ} \mathrm{C} \text { for } 40 \mathrm{sec} \\
\text { Strand extension temperature }: 72^{\circ} \mathrm{C} \text { for } 80 \mathrm{sec} \\
\text { Final extension temperature : } 72^{\circ} \mathrm{C} \text { for } 4 \mathrm{~min}\end{array}$ \\
\hline
\end{tabular}


mixture $(25 \mu \mathrm{L})$ contained the following: $15 \mu \mathrm{L}$ of PCR Master Mix (Sisco Research Laboratories PVT LTD, Mumbai, India), $1 \mu \mathrm{M}(1 \mu \mathrm{L})$ each primer (Eurofins MWG Operon, Germany), $2 \mu \mathrm{L}$ ( $\pm 50 \mathrm{ng}$ ) gDNA and the remaining volume was adjusted with sterile distilled water. PCR amplification was performed with a thermal cycler (GenePro, Hangzhou Bioer Tech Co. Ltd., China) with PCR condition as described in Table 1. The fragments were separated under agarose gel electrophoresis and further visualized under the gel documentation system (UVP GelDoc-IT 310 Imaging System, Upland CA).

PCR amplicon of $r b c L$ region was purified using QIA quick gel extraction kit (Qiagen, Maryland, USA). Direct sequencing of the purified PCR amplicon was done by Eurofins Genomics India Pvt. Ltd., Germany. Forward and reverse DNA sequencing reaction of PCR amplicon was carried out using BDT v3.1 Cycle sequencing kit on ABI 3730xl Genetic Analyzer. Consensus sequence of the PCR amplicon was generated from forward and reverse sequence data using aligner software. The rbcL region sequences were converted to FASTA format and used for BLAST at the NCBI web page (http://blast.ncbi.nlm.nih. gov/Blast), then selecting reference data domain as nucleotide collection (nt/nr) for highly similar mega-blast search. The sequence data of a query sample was compared to a reference sequence generated from a well identified and voucher specimen of NCBI database [9].

\section{Phylogenetic Analysis}

BLAST Sequences were aligned using BioEdit ver. 7.0.5 sequence alignment editor multiple alignment program Clustal W. The phylogeny was inferred with the Neighbor-Joining method by using Kimura-2-parameter model through MEGA version 7 [10]. The bootstrap consensus tree inferred from 1000 replicates was taken to represent the evolutionary relationship of the taxa analyzed. Branches having less than $50 \%$ bootstrap values were merged into higher valued branches. Preliminary tree(s) for the heuristic search were acquired consequently by pertaining BioNJ calculations to a lattice of pair wise separations evaluated utilizing the Maximum Composite Likelihood (MCL) approach, at that point choosing the topology with predominant log likelihood value. Codon positions included were $1 s t+2 n d+3 r d+$ Noncoding. Based on maximum identity score first ten sequences were selected for the evolutionary divergence between the sequences estimated using Disparity Index Test of Substitution Pattern Homogeneity [11].

\section{RESULTS AND DISCUSSION}

\section{Standardization of Barcode Genes}

The voucher specimen of taxonomically identified plant species i.e. Indopiptadenia oudhensis was submitted to DD Herbarium (Accession no. of 172250) (Fig. 1b) and the same was subjected to further molecular study. The method given by Kumar et al. [7] with some modifications produced ample quantity (529-1419 ng/ul) with range of quality gDNA (OD: 1.52-1.97). Indeed, DNeasy Mini Plant Kit-QIAGEN yielded an excellent quality of DNA (OD: 1.76-1.84). The yield (DNA concentration) was comparatively very low approximately 28.8 $32.5 \mathrm{ng} / \mathrm{ul}$. So, DNA isolation process by DNeasy Mini Plant Kit-QIAGEN was repeated 4 to 5 times to obtain the required amount of DNA [12]. The DNA sample taken for further molecular study was used with OD (260/280 ratio) of 1.81 and concentration of $745 \mathrm{ng} / \mathrm{ul}$ approximately extracted by Kumar et al. [7] with modifications that was highly suitable for further molecular study. Three universal barcode genes (i.e. rbcL, matK, ITS) were tried, while satisfactory amplification was obtained with the rbcL ( $\mathrm{aF} \& \mathrm{aR})$. A single discrete PCR amplicon band of $\sim 700 \mathrm{bp}$ was observed when resolved on agarose. Universal primer matK (390F \& 1326R) was not successfully amplified. In contrast, there are several matK sequences available for other mimosoid genera but couldn't generate consensus sequence data for sample due to mixed reads. However, ITS region showed amplification but resolution was not so optimal. Therefore, ITS was not considered for phylogenetics in present study.

The present study clearly supported that the most common gene used to provide sequence data for plant phylogenetic analyses is the plastid-encoded $r b c L$ gene. The Consortium for the Barcode of Life (CBOL) plant working group has recommended $r b c L$ and matK as standard genes for the barcoding of land plants $[13,14]$, though $r b c L$ has limitation to resolve phylogenetic relationships below the family level [5]. It is still expected that a system which is made up of any one or a combination of plastid genes was not be successful in the targeted taxa that exhibited low amounts of plastid variation, while working well in other groups [15]. Recently, $r b c L$ is widely used for developing the barcodes for land plants [16]. However, using more than one primer pair can be time consuming as well as costly and is often complex for large-scale projects [17]. It may be due to high-quality sequences of $r b c L$ which are easily retrievable across phylogenetically divergent lineages and it performs well in discrimination tests in combination with other loci [14].

\section{Molecular Phylogenetics}

Total nucleotide frequencies were 27.3\% for Adenine (A), $28.3 \%$ for Thymine (T), 21.2 for Cytosine (C) and 23.1\% for Guanine (G) in its amplified fregment with the total nucleotide of 575 . Sequence producing significant alignments with NCBI database is presented in Table 2 for first ten closest sequences based on nucleotide homology. Further evolutionary divergence matrix was produce by using 10 closely related species sequences already submitted on NCBI. BLAST results showed highest similarity with Prosopis cineraria based on the nucleotide homology. However, sequence section obtained by $r b c L$ primer-set subjected sequence discriminated the species from $P$. cineraria and demonstrated nucleotide variations at 1 site only (552; A $>$ G) (Fig. 2). During the BLAST search, no sequence matches for $r b c L$ gene could be identified from GenBank databases on plant. Hence, the rbcL sequence of I. oudhensis may be useful for further molecular identification. There were a total of 566 positions in the final dataset. Estimates of Evolutionary Divergence between Sequences through Disparity Index Test of Substitution Pattern Homogeneity showed genetic 
similarities to the same species accession whose sequence was already submitted to the NCBI Genbank database (Table 3). Thus, the molecular identification scheme proposed herein will provide better genetic definition of large collections of strains representing named species and will then serve as the basis for a large-scale phenotypic study to determine better biochemical tests to separate taxa. Such studies are less conducted in forest tree species rather than fungus and bacteria [18].

Neighbor-Joining analysis of $r b c L$ sequence of I. oudhensis was inferred for phylogeny with the closely related 100 sequences of different species (Fig. 3). Sequences producing significant

\begin{tabular}{|llll|}
\hline Query & 483 & GTACGGCCGTCCCCTATTGGGATGTACTATTAAACCAAAAT \\
Sbjct & 483 & GTACGGCCGTCCCCTATTGGGATGTACTATTAAACCAAAAT \\
Query & 543 & TTACGGTAGAGCGGTTATGAATGTCTCCGC & 573 \\
Sbjct & 543 & TTACGGTAGGGGGGTTATGAATGTCTCCGC & 573 \\
\hline
\end{tabular}

Figure 2: Alignment of $P$. cineraria (Query) and $I$. oudhensis (Subject sequence) partial $r b c L$ gene sequences. Arrows indicate the nucleotide variation between the two sequences (552; $A>G)$ alignments give us an idea about the phylogenetic closeness of Indopiptadenia oudhensis to the Piptadenia communis, Acacia karroo, Acacia pachyceras, Vachellia tortilis, Vachellia nilotica, Pithecellobium flexicaule, Archidendron hirsute, Pararchidendron pruinosum etc. belongs to Mimosoid clade of subfamily Mimosoideae. It may be due to the same floral characters i.e. actinomorphic symmetry, numerous florets, bracts $c .1 \mathrm{~mm}$ long and caduceus, pedicellate, calyx c. $1 \mathrm{~mm}$ long, corolla glabrous, pistil glabrous in all species. On the other hand, Indopiptadenia oudhensis shows the closeness with the members of subfamily Caesalpinoideae i.e. Mezoneuron acullatum (Caesalpinia clade), Haematoxylom brasiletto (Cassia clade), Ceratonia siliqua (Umtiza clade), Parkinsonia microphylla (Peltophorum clade), Caesalpinia calycina (Caesalpinia clade), Libidibia coriaria (Caesalpinia clade), Senna tora (Cassia clade) and S. auriculata etc. It may be due to having same number of anthers, number of leaflets and few similar pod characters. Thus, it is said that Indopiptadenia oudhensis may be the connecting species between subfamilies Mimosoideae and Caesalpinoideae.

The present results are in accordance with the information published by Legume Phylogeny Working Group [6].

Table 2: BLAST search results for Indopiptadenia oudhensis sequences showing similarity with the other species accessions from NCBI database

\begin{tabular}{|c|c|c|c|c|c|c|}
\hline Description & Max score & otal score & Query cover & $\mathrm{E}$ value & Identity (\%) & Accession \\
\hline $\begin{array}{l}\text { Prosopis cineraria isolate UMS R12 ribulose-1,5-bisphosphate carboxylase/ } \\
\text { oxygenase large subunit }(r b c L) \text { gene }\end{array}$ & 1050 & 1050 & $99 \%$ & 0 & $99 \%$ & KU365410.1 \\
\hline $\begin{array}{l}\text { Senna tora voucher CIMAP:C037 ribulose-1,5-bisphosphate carboxylase/ } \\
\text { oxygenase large subunit }(r b c L) \text { gene, partial cds; chloroplast }\end{array}$ & 1029 & 1029 & $100 \%$ & 0 & $99 \%$ & KY464124.1 \\
\hline $\begin{array}{l}\text { Senna tora voucher CIMAP:C030 ribulose-1,5-bisphosphate carboxylase/ } \\
\text { oxygenase large subunit }(r b c L) \text { gene }\end{array}$ & 1029 & 1029 & $100 \%$ & 0 & $99 \%$ & KY464123.1 \\
\hline $\begin{array}{l}\text { Senna tora voucher JKTM-1-000064 ribulose-1,5-bisphosphate carboxylase/ } \\
\text { oxygenase large subunit }(r b c L) \text { gene }\end{array}$ & 1029 & 1029 & $100 \%$ & 0 & $99 \%$ & KP058311.1 \\
\hline $\begin{array}{l}\text { Senna auriculata isolate TMP177 ribulose 1,5-bisphosphate carboxylase/ } \\
\text { oxygenase large subunit ( } r b c L \text { ) gene }\end{array}$ & 1027 & 1027 & $99 \%$ & 0 & $99 \%$ & KF425769.1 \\
\hline $\begin{array}{l}\text { Senna occidentalis isolate TMP60 ribulose 1,5-bisphosphate carboxylase large } \\
\text { subunit }(r b c L) \text { gene }\end{array}$ & 1027 & 1027 & $99 \%$ & 0 & $99 \%$ & KF381138.1 \\
\hline $\begin{array}{l}\text { Acacia pachyceras voucher EDNA15-0042390 ribulose-1,5-bisphosphate } \\
\text { carboxylase/ oxygenase large subunit }(r b c L) \text { gene }\end{array}$ & 1026 & 1026 & $100 \%$ & 0 & $99 \%$ & KX282508.1 \\
\hline $\begin{array}{l}\text { Vachellia tortilis isolate UMS R65 ribulose-1,5-bisphosphate carboxylase/ } \\
\text { oxygenase large subunit }(r b c L) \text { gene }\end{array}$ & 1026 & 1026 & $99 \%$ & 0 & $99 \%$ & KX015750.1 \\
\hline $\begin{array}{l}\text { Vachellia nilotica ribulose-1,5-bisphosphate carboxylase/ oxygenase large } \\
\text { subunit }(r b c L) \text { gene }\end{array}$ & 1026 & 1026 & $99 \%$ & 0 & $99 \%$ & KC417042.1 \\
\hline $\begin{array}{l}\text { Senna tora voucher CIMAP:C044 ribulose-1,5-bisphosphate carboxylase/ } \\
\text { oxygenase large subunit }(r b c L) \text { gene }\end{array}$ & 1024 & 1024 & $99 \%$ & 0 & $99 \%$ & KY464125.1 \\
\hline
\end{tabular}

Table 3: Estimates of Evolutionary Divergence of $r b c L$ sequences of Indopiptadenia oudhensis with their similar sequences through BLAST search

\begin{tabular}{|c|c|c|c|c|c|c|c|c|c|c|c|}
\hline Indopiptadenia oudhensis & & 0.002 & 0.004 & 0.004 & 0.134 & 0.004 & 0.004 & 0.004 & 0.004 & 0.004 & 0.004 \\
\hline Prosopis cineraria & 0.002 & & 0.005 & 0.005 & 0.139 & 0.005 & 0.005 & 0.004 & 0.004 & 0.005 & 0.005 \\
\hline Senna tora & 0.011 & 0.012 & & 0.000 & 0.125 & 0.004 & 0.004 & 0.006 & 0.006 & 0.006 & 0.000 \\
\hline Senna tora & 0.011 & 0.012 & 0.000 & & 0.125 & 0.004 & 0.004 & 0.006 & 0.006 & 0.006 & 0.000 \\
\hline Senna tora & 1.282 & 1.294 & 1.255 & 1.255 & & 1.135 & 0.135 & 0.131 & 0.131 & 0.123 & 0.125 \\
\hline Senna auriculata & 0.011 & 0.012 & 0.007 & 0.007 & 1.288 & & 0.000 & 0.006 & 0.006 & 0.006 & 0.004 \\
\hline Senna occidentalis & 0.011 & 0.012 & 0.007 & 0.007 & 1.288 & 0.000 & & 0.006 & 0.006 & 0.006 & 0.004 \\
\hline Acacia pachyceras & 0.011 & 0.012 & 0.022 & 0.022 & 1.276 & 0.022 & 0.022 & & 0.000 & 0.004 & 0.006 \\
\hline Vachellia tortilis & 0.011 & 0.012 & 0.022 & 0.022 & 1.276 & 0.022 & 0.022 & 0.000 & & 0.004 & 0.006 \\
\hline Vachellia nilotica & 0.011 & 0.013 & 0.018 & 0.018 & 1.243 & 0.022 & 0.022 & 0.007 & 0.007 & & 0.006 \\
\hline Senna tora & 0.011 & 0.012 & 0.000 & 0.000 & 1.255 & 0.007 & 0.007 & 0.022 & 0.022 & 0.018 & \\
\hline
\end{tabular}




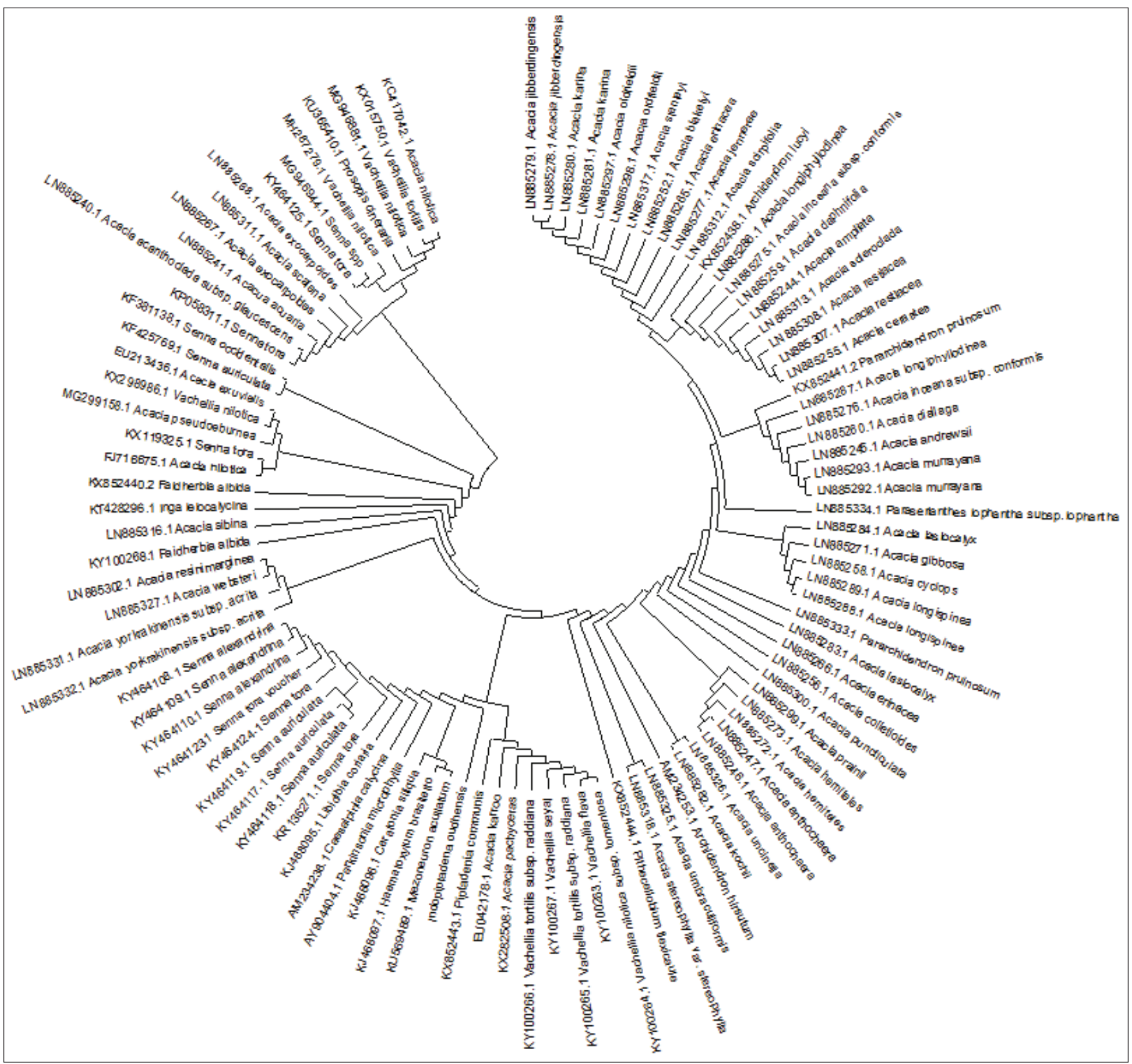

Figure 3: Phylogenetic relationship of Indopiptadenia oudhensis with their similar sequences through BLAST search based on Neighbor-Joining (NJ) analysis of $r b c L$ sequence

They clearly mentioned that the traditionally recognized subfamily Mimosoideae is a distinct clade nested within the recircumscribed Caesalpinioideae. The subfamily Mimosoideae is probably the least understood from a phylogenetic perspective. While, it has generally been accepted that the Mimosoideae was monophyletic, and derived from caesalpinioid ancestors [19], the traditional "boundary" between the two subfamilies, with mimosoids distinguished by valvate aestivation of sepals, is not distinct. Bentham [20] considered Indopiptadenia oudhensis in tribe Piptadenieae of mimosoid but it differs from tribe mimoseae due to absence of endosperm in seed which prompted the reassignment of a few genera. Hutchinson [21] adopted the Bentham's unique classification system by perceiving the tribe Adenantherae (analogous to Piptadenieae) in view of appearance or nonappearance of anther glands. Bentham's tribe Mimoseae was combined into Piptadenieae based on endosperm characters by Lewis and Elias [22] and furthermore, explained the antiquity of both tribes for other important characters. Chappill and Maslin [23] included the morphological characters to prepare the cladogram in which they presented the members of the Piptadenia group as sister clade to the Acacieae and Ingeae tribe. Luckow et al. [19] also represented Piptadenia group of Mimoseae including the members of Acacieae and Ingeae.

Morphologically, Indopiptadenia oudhensis was first described by Dietrich Brandis in 1874 with the name of Piptadenia 
Bentham (1840: 135) and till 1955, it was considered part of this genus. Piptadenia is a tropical South American genus with c. 15 species [22]. Brenan [24] observed that the Indian plant identified as Piptadenia oudhensis Brandis (1874: 168) do not fit into Piptadenia because they have leaves that consist of 1 or 2 pairs of pinnae, the pinnae being uni- or bijugate, eglandular petiole, glandular leaf rachis, free corolla lobes and elongated seeds; he thus erected a new genus Indopiptadenia to accommodate the Indian plants. However, Brenan [24] mentioned that Indopiptadenia has greater morphological affinity with Piptadenia as both have pods that dehisce along both the sutures. Recently, Luckow [25] has mentioned that Indopiptadenia has a superficial affinity with Piptadenia and following Lewis and Elias [22] placed the genus in the Newtonia group of tribe Mimoseae Bronn (1822: 130). Lewis and Elias [22] separated this species from the Piptadenia group chiefly based on: pedicels jointed with generally persistent basal part, petals free, anther gland present, pollen grains single, intrastaminal disc present, style tip tubular, fruits long, flat, coriaceous, opening along one margin or both and seeds winged [1]. Indopiptadenia is undoubtedly closer to the Newtonia group, but it differs in having unarmed to armed stem, uni- or bijugate leaflets, absence of stemonozone and dehiscence of pods by rupturing of the fruit wall at the seed position. It suggests that Indopiptadenia requires a separate identity within the tribe Mimoseae based on morphology. The present results are in confirmation with the previous statement and also said that it could be the connecting species between Mimosioideae and Caesalpinioideae based on present phylogram.

\section{ACKNOWLEDGEMENTS}

Authors are grateful to Director, Forest Research Institute Dehradun, India for providing the facilities. Corresponding author is graceful to the Head, Department of Forestry, Punjab Agricultural University Ludhiana, India to grant the leave to complete the work over there.

\section{AUTHOR CONTRIBUTIONS}

$\mathrm{AKD}, \mathrm{AC}$ and AT conceived and designed the study. AKD, RK and SS collected field data. PKV taxonomically identified the plant sample. AKD and VVP led laboratory wok, data analysis, AKD wrote the first draft of the manuscript and all further revisions. All authors gave final approval for publication.

\section{DATA AVAILABILITY}

All relevant data are within this paper. Authors have declared that no competing interests exist.

\section{REFERENCES}

1. Bajpai O, Srivastava AK, Kushwaha AK, Chaudhary LB. Taxonomy of a monotypic genus Indopiptadenia (Leguminosae-Mimosoideae). Phytotaxa. 2014; 164(2): 61-78.

2. Champion HG, Seth SK. A Revised Survey of the Forest Types of India, Publication Division, Govt. of India, New Delhi, India, pp 404; 1968.
3. Chandra A, Dhakad AK, Kewat A. Regeneration pattern of Indopiptadenia oudhensis - a threatened species. Indian Journal of Pharmacology. 2017; 40(2): 193-195.

4. Bentham G, Hooker JD. Genera Plantarum, Volume I., London, UK, 1862-1883.

5. Dhakad AK. Molecular phylogeny of selected tree species of families Fabaceae, Caesalpiniaceae and Mimosaceae of Uttarakhand. Ph.D. thesis, Forest Research Institute (Deemed) University, Dehradun, India, 2017.

6. The Legume Phylogeny Working Group. A new subfamily classification of the Leguminosae based on a taxonomically comprehensive phylogeny. Taxon. 2017; 66(1): 44-77.

7. Kumar A, Pushpangadan P, Mehrotra S. Extraction of high molecular weight DNA from dry root tissue of Berberis /ycium suitable for RAPD. Plant Molecular Biology Reporter. 2003; 21: 309a-309d.

8. Dhakad AK, Chandra A, Barthwal S, Thakur A, Rawat JM. Analysis of phylogeny and evolutionary divergence of Acacia catechu (L.f.) Willd. based on $r b c L$ conserved sequence. International Journal of Biological Sciences. 2017; 8(2): 89-95.

9. Schori M, Showalter AM. DNA barcoding as a means for identifying medicinal plants of Pakistan. Pakistan Journal of Botany. 2011; 43: 1-4.

10. Kumar S, Stecher G, Tamura K. MEGA7: Molecular Evolutionary Genetics Analysis version 7.0 for bigger datasets. Molecular Biology and Evolution. 2016; 33(7): 1870-1874.

11. Dhakad AK, Chandra A, Barthwal S, Thakur A, Rawat JM. DNA extraction and molecular characterization of Acacia pseudoeburnea - An endemic species. Research Journal of Biotechnology. 2018; 13(8): 72-78.

12. Dhakad AK, Chandra A, Thakur A. First report of DNA extraction in Indopiptadenia oudhensis (Brandis) Brenan- Critical endangered endemic species. In: Proceeding of National Symposium on Agroforestry challenges, sustainable landuse, biodiversity conservation and rural livelihood options- Short communication, pp 205: 2016.

13. Kress J, Erickson DL. A two-locus global DNA barcode for land plants: the coding $r b c L$ gene complements the non-coding $t r n H-p s b A$ spacer region. Plos One. 2007; 2: e508.

14. CBOL Plant Working Group. A DNA barcode for land plants. Proceedings of the National Academy of Sciences of the United States of America. 2009; 106: 12794-12797.

15. Newmaster SG, Ragupathy S. Testing plant barcoding in a sister species complex of pantropical Acacia (Mimosoideae, Fabaceae). Molecular Ecology Resources. 2009; 9: 172-180.

16. Hollingsworth PM, Graham SW, Little DP. Choosing and using a plant DNA barcode. Plos One. 2011; 6: e19254.

17. Heckenhauer J, Barfuss MHJ, Samuel R. Universal multiplexable matK primers for DNA barcoding of angiosperms. Applications in Plant Sciences. 2016; 4(6): 1-7.

18. Scola BL, Gundi AKB, Khamis A, Raoult D. Sequencing of the $r p o B$ Gene and flanking spacers for molecular identification of Acinetobacter species. Journal of Clinical Microbiology. 2006; 44(3): 827-832.

19. Luckow M, White PJ, Bruneau A. Relationships among the basal genera of mimosoid legumes. In: Herendeen PS, Bruneau A. (editors) Advances in Legume Systematics, part 9, Royal Botanic Gardens, Kew, UK, pp 165-180; 2000

20. Bentham G. Revision of the suborder Mimoseae. Transactions of the Linnean Society of London. 1875; 30: 335-664.

21. Hutchinson J. The genera of flowering plants, Volume 1. Oxford at Clarendon Press, Amen House, London, UK, 1964.

22. Lewis GP, Elias TS. Mimoseae. In: Polhill RM, Raven PH. (editors) Advances in legume systematics, part 1, Royal Botanic Gardens, Kew, UK, pp 155-168; 1981.

23. Chappill JA, Maslin BR. A phylogenetic assessment of tribe Acacieae. In: Crisp MD, Doyle JJ. (editors) Advances in legume systematics, part 7, Phylogeny, Royal Botanic Gardens, Kew, UK, pp 77-99; 1995.

24. Brenan JPM. Notes on Mimosoideae. Kew Bulletin. 1955; 10(2): 178-179.

25. Luckow M. Tribe Mimoseae. In: Lewis G, Schrire B, Mackinder B, Lock M. (editors) Legumes of the World, Royal Botanic Gardens, Kew, UK, pp 163-183; 2005. 